\title{
Frequencies of Some Morphological Features in Indigenous Chickens of South- Western Nigeria \\ Adebambo $^{1 *}$, A. O., Adeoye ${ }^{1}$, R.A., Osikomaya. ${ }^{1}$, O.A., Durosaro ${ }^{1}$, S.O., Ilori ${ }^{1,2}$, B.M. Sanda ${ }^{1}$, A.J., Wheto ${ }^{1}$, M. and Adebambo ${ }^{1}$, O.A. \\ ${ }^{1}$ Department of Animal Breeding and Genetics, Federal University of Agriculture, Abeokuta, Nigeria. ${ }^{2}$ School of Biology, University Park, University of Nottingham,

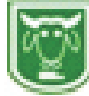 \\ Nottingham NG7 2RD, United Kingdom \\ *Corresponding author: tumininuadebambo@yahoo.com
}

\begin{abstract}
Morphological features of chicken genetic resources must be carefully identified and considered in developing breeding strategies. The study was carried out to determine the frequencies of morphological features in indigenous chickens of South-Western Nigeria, using Lagos, Ogun, Osun and Oyo States as case study. Five major chicken markets (Mushin in Lagos State, Itoku and Ipokia in Ogun State, Olu-ode in Osun State and Molete in Oyo State) were used as study locations and three thousand, three hundred and thirteen chickens were observed in the five locations. Ipokia had the highest number (1,549) of chickens and Molete had the least (307) number of chickens. The traits observed included: feather structure, feather distribution, feather morphology, plumage colour, ear lobe colour, skin colour and shank colour. The data collected were subjected to descriptive statistics and inferential statistical analysis was also done for the results using chi-square test. It was observed that for those traits that recorded significant variation, there had been selection for these traits due to the high market value attached to them by attaching preference to some of its variants which were observed. Knowledge and well documentation of the potentials of indigenous chickens can help provide crucial information for a comprehensive breeding policy and full utilization of the animal.
\end{abstract}

Keywords: Characterization, conservation, indigenous chickens, morphological features

\section{Introduction}

Identification and characterization of Nigerian indigenous chickens require information on their population, adaptation to a specific environment, possession of traits of current or future value and sociocultural importance, which are crucial inputs to decisions on conservation and utilization (Weigend and Romanov, 2001).

Nigerian indigenous chickens are important reservoirs of useful genes and possess a number of adaptive traits (Horst, 1989). They are widely distributed in the rural areas where they are kept by the majority of the rural dwellers. They are generally hardy, adaptive to rural environments, survive on little or no inputs and adjust to fluctuations in feed availability. Nigerian indigenous chickens are found scattered in hamlets, villages, towns and cities (Oni, 1999). Nigerian indigenous chickens lay 8-9 eggs/clutch within a laying period of 12-14 days. Rearing period is 64-70 days and the age at point of lay is 32-36 weeks (Ikeobi et al., 1996).

A survey of indigenous chickens of SouthWestern Nigeria was carried out between 1995 and 1996 by Adebambo et al. (1999) to evaluate the effect of colour variation on relative performance characteristics as a selection criterion for development of 
improved indigenous poultry types for the Nigerian market. Phenotypic colour variance of feather and shank suggested that selection based on these colour variances could be effective in breed development (Adebambo et al., 1999). Report from Kerje et al. (2003) provided convincing evidence that this locus is orthologous to the classic mammalian coatcolour E-locus (MC1R; extension), the inheritance is autosomal and this phenotype is not considered as a defect. The white feather in chicken inheritance is autosomal recessive and chocolate feather colour might be a sex-linked inherited trait.

Nigerian indigenous chickens can be classified based on the wing type. The short winged $(S w)$ Nigerian indigenous chickens are locally called "opipi or Lepipi" by the Yorubas. Short winged chicken feathers are brittle and they give a crack sound when broken. The naked neck $(\mathrm{Na})$ chickens are locally called "Abolorun" and the frizzle feather chicken is usually called "Asa" by the Yorubas. The silky feather $(H)$ chickens have also been discovered recently and they have a fluffy-like feather. The chickens with this type of feather are locally called "Oloyeye" by the Yorubas. Another way of classifying the indigenous chicken breeds is by using their plumage colour. There are some other birds with distinct features such as Ross comb (locally called $L e^{\prime} s u$ by the Yorubas) and rumples bird.

There is no recent work on classification of Nigerian indigenous chickens based on their morphological features and their distribution. Knowledge generated from this study will aid in decision making on conservation and utilization programmes for the indigenous chicken strains. This study aims to identify and determine the frequencies of morphological features of indigenous chicken breeds in South-
Western Nigeria.

\section{Materials and Methods Study locations}

This study was conducted in the SouthWestern part of Nigeria. The area falls between Latitude $7^{\circ} 10^{\prime} \mathrm{N}$ and Longitude $3^{\circ}$ $2^{\prime} \mathrm{E}$. The area has two main climatic seasons which are wet season and dry season. It has a prevailing tropical climate with a mean rainfall of about $1037 \mathrm{~mm}$ and mean ambient temperature ranging between $20^{\circ}$ $30^{\circ} \mathrm{C}$ with a yearly average of $34^{\circ} \mathrm{C}$. Its vegetation depicts an inter-phase between the tropical rainforest and the derived savannah. Five major chicken markets (Mushin in Lagos State, Itoku and Ipokia in Ogun State, Olu-Ode in Osun State and Molete in Oyo State) were used as the study locations around the whole of SouthWestern States of Nigeria. The ecological and demographic characteristics of the study locations are shown in Table 1.

Data collection

A list of physical descriptors was prepared to record both qualitative morphological characters and certain quantitative traits as described by Dana et al. (2010). In each of the study regions, chicken markets which were at least $100 \mathrm{~km}$ apart that sell local chickens were selected. Chicken sellers were interviewed to describe the mode of sourcing of the flock. In each market, the population census was taken for all birds by simple head count. Records were taken and kept for all birds in the markets visited by a team of researchers between February and April 2011 based on the following features: feather distribution, feather morphology, plumage colour, ear-lobe colour, shank colours, skin colour and feather structure (Plate 1-5). Data collected were analyzed 
Adebambo, Adeoye, Osikomaya., Durosaro, Ilori, , Sanda, Wheto and Adebambo

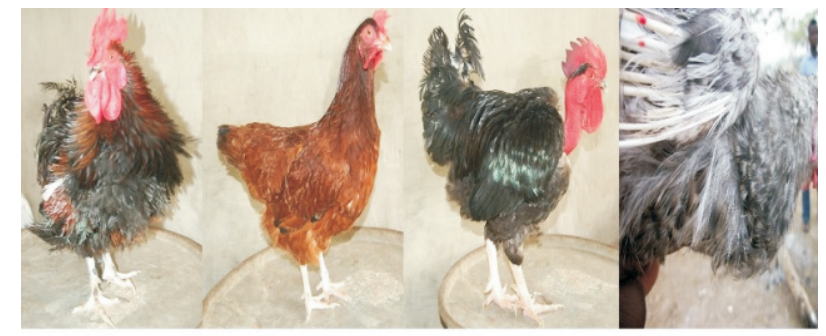

Frizzle feather Normal feather

Naked neck

Silky feather

Plate 1. Feather structure and distribution

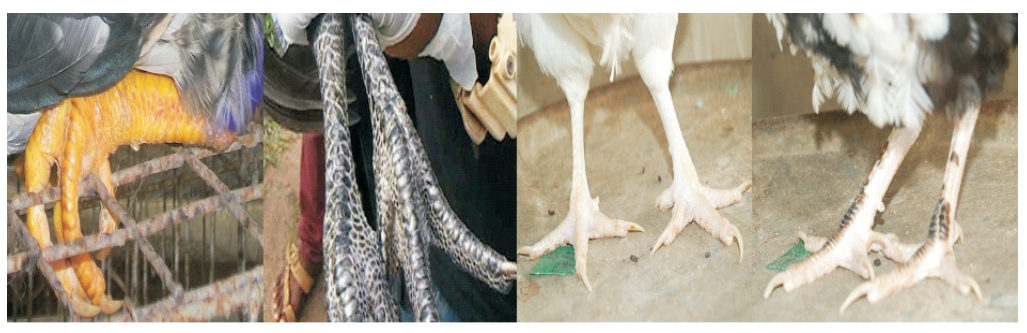

Yellow shank Black shank White shank Mottled shank

Plate 2. Shank

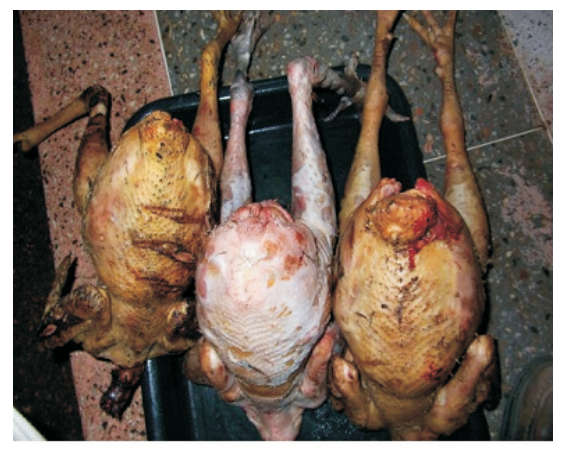

White and Yellow skin

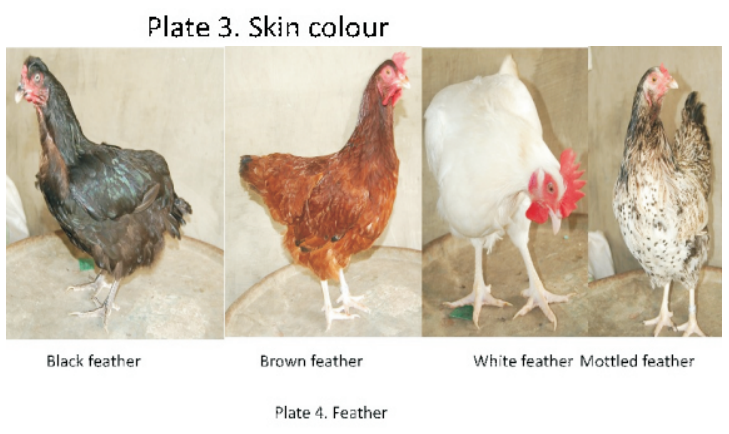

6 
Morphological features in indigenous chickens of South-Western Nigeria

Table 1: Ecological and demographic characteristics of the study locations

\begin{tabular}{|c|c|c|c|c|}
\hline & Lagos & Oyo & Ogun & Osun \\
\hline Land mass $\left(\mathrm{km}^{2}\right)$ & 3,577 & 28,454 & $16,980.55$ & 9,251 \\
\hline Height (m) & 10 & 267 & 77 & 246 \\
\hline Population & $9,019,534$ & $6,617,720$ & $3,751,140$ & $4,137,627$ \\
\hline Density (per km²) & 2,500 & 200 & 220 & 240 \\
\hline Latitudinal position & Equatorial & Equatorial & Equatorial & Equatorial \\
\hline Season & Dry and wet season & Dry and wet season & $\begin{array}{l}\text { Dry and wet } \\
\text { season }\end{array}$ & $\begin{array}{l}\text { Dry and wet } \\
\text { season }\end{array}$ \\
\hline Humidity & High humidity & High humidity & High humidity & High humidity \\
\hline Dry season & Nov-march & Nov-march & Nov-march & Nov-march \\
\hline Wet season & April-oct & April-oct & April-oct & April-oct \\
\hline Average daily temp $\left({ }^{\circ} \mathrm{C}\right)$ & $25-35$ & $25-35$ & $25-35$ & $25-35$ \\
\hline Major water bodies & $\begin{array}{l}\text { Coastal area. Southern region is } \\
\text { bordered by the Atlantic. } \\
\text { Lagoons and estuaries }\end{array}$ & Ogunpa River & Ogun River & Osun River \\
\hline Vegetation & Swamp forest and coastal belt & $\begin{array}{l}\text { Tropical rain forest } \\
\text { in the south and } \\
\text { guinea savannah in } \\
\text { the north }\end{array}$ & $\begin{array}{l}\text { Tropical rain } \\
\text { forest in the south } \\
\text { and derived } \\
\text { savannah in the } \\
\text { north }\end{array}$ & $\begin{array}{l}\text { Tropical rain } \\
\text { forest }\end{array}$ \\
\hline
\end{tabular}

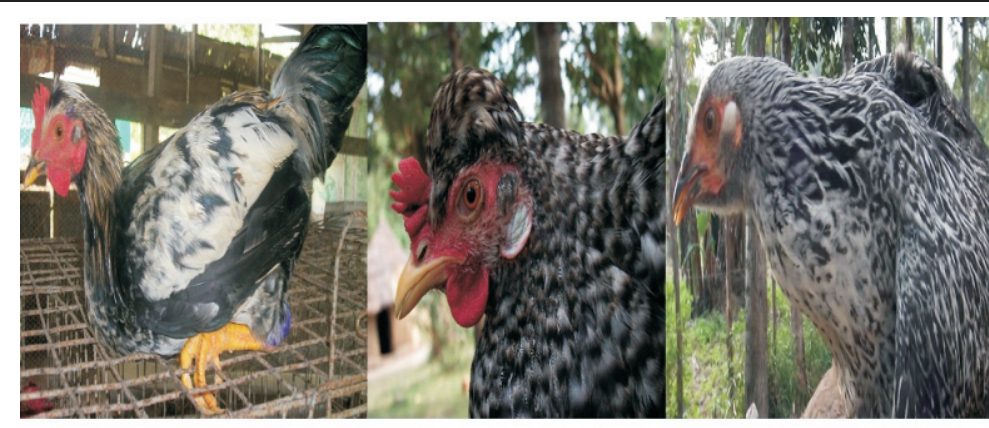

Red ear lobe

White ear lobe

Yellow ear lobe

Plate 5. Ear lobe 
using descriptive statistics and $\chi^{2}$-test. Gene frequencies were calculated for the morphological features using the HardyWeinberg equilibrium principle below:

$\mathrm{p}+\mathrm{q}=1$

Where $\mathrm{p}$ is the dominant allele and $\mathrm{q}$ is the recessive allele

\section{Results and Discussion}

The morphological features of Nigerian indigenous chickens and their frequencies are shown in Table 2. The feather distribution had two variants which were normal $(2,547)$ and naked $(766)$ neck and this is in agreement with the reports of Dana et al. (2010) where all the Ethiopian locations studied had more normal feathered chickens. Selection for feather distribution is based on human preference due to economic and aesthetic values. Although the naked gene is a gene with desirable effects on adult fitness and heat tolerance, the number of chickens that expressed the gene was very small. Farmers don't prefer the naked neck chickens (Aklilu, 2007) and this favours selection against this valuable gene. Thus, it appears that the future of the naked neck gene is at stake unless measures are taken towards its conservation (Dana et al., 2010). Various feather types are essential characteristics of domestic chicken breeds (Wildelitz et al., 2007). Birds belonging to the indigenous strains of chicken have developed this features based on the expression of adaptive major genes for frizzling $(F)$, naked neck $(N a)$ and the dwarf genes $(d w)$ (Ikeobi et al., 1996). Feathers have complex forms and are an excellent model to study the development and evolution of morphologies (Ng et al., 2012). Observations on early maturity of birds with either the $\mathrm{F}$ or the $\mathrm{Na}$ gene relative to those with normal feathering had been made by Ibe $(1992,1993)$. The advantages of the $F$ and $\mathrm{Na}$ genes over normal feathering conditions would probably be exhibited during egg production (Ibe, 1993). It has also been reported by Gunn (2008) that the frizzled gene and necked genes conferred better feed conversion on those genotypes when compared to their normal counterpart in respect to weight gain, although some communities attach

\begin{tabular}{|c|c|c|c|c|c|c|c|}
\hline Trait & Variant & $\begin{array}{l}\text { Observed } \\
\text { Proportion }\end{array}$ & $\begin{array}{l}\text { Expected } \\
\text { Proportion }\end{array}$ & $\begin{array}{l}\text { Observed } \\
\text { Gene } \\
\text { Frequency }\end{array}$ & $\begin{array}{l}\text { Expected } \\
\text { Gene } \\
\text { Frequency }\end{array}$ & $\chi^{2}$ test & $\begin{array}{l}\text { Gene } \\
\text { Notation }\end{array}$ \\
\hline Feather distribution & $\begin{array}{l}\text { Normal } \\
\text { Naked }\end{array}$ & $\begin{array}{l}2,547 \\
766\end{array}$ & $\begin{array}{l}2138 \\
494\end{array}$ & $\begin{array}{l}0.78 \\
0.22\end{array}$ & $\begin{array}{l}0.77 \\
0.23\end{array}$ & $1.62178^{\mathrm{NS}}$ & $\begin{array}{l}\mathrm{N}^{+} \\
\mathrm{Na}\end{array}$ \\
\hline \multirow[t]{2}{*}{ Feather Morphology } & Normal & 2,948 & 2138 & 0.86 & 0.89 & & $\mathrm{~N}^{+}$ \\
\hline & $\begin{array}{l}\text { Silky } \\
\text { White }\end{array}$ & $\begin{array}{l}365 \\
201\end{array}$ & $\begin{array}{l}494 \\
164\end{array}$ & $\begin{array}{l}0.14 \\
0.05\end{array}$ & $\begin{array}{l}0.11 \\
0.60\end{array}$ & $4.81412 *$ & $\begin{array}{l}\mathrm{H}^{+} \\
\mathrm{W}^{+}\end{array}$ \\
\hline \multirow{3}{*}{ Plumage Colour } & Black & 959 & 494 & 0.28 & 0.29 & & $\mathrm{E}^{+}$ \\
\hline & Brown & 683 & 494 & 0.17 & 0.21 & & $\mathrm{Db}$ \\
\hline & Mottle & 1,410 & 1480 & 0.49 & 0.43 & $9.5974^{*}$ & Mo \\
\hline \multirow[t]{3}{*}{ Ear-Lobe Colour } & White & 669 & 658 & 0.19 & 0.20 & & $\mathrm{~W}^{+}$ \\
\hline & Yellow & 894 & 494 & 0.19 & 0.27 & & $\mathrm{Y}^{+}$ \\
\hline & Red & 1,760 & 1480 & 0.63 & 0.53 & $1.33673^{\mathrm{NS}}$ & $\mathrm{Rs}^{+}$ \\
\hline \multirow[t]{2}{*}{ Skin Colour } & White & 1,259 & 494 & 0.34 & 0.38 & & $\mathrm{~W}^{+}$ \\
\hline & Yellow & 2,054 & 2138 & 0.66 & 0.62 & $2.5152^{\mathrm{NS}}$ & $\mathrm{Y}^{+}$ \\
\hline \multirow[t]{4}{*}{ Shank Colour } & White & 1,066 & 494 & 0.34 & 0.32 & & $\mathrm{~W}^{+}$ \\
\hline & Yellow & 1,192 & 1480 & 0.34 & 0.36 & & $\mathrm{Y}^{+}$ \\
\hline & Black & 695 & 494 & 0.23 & 0.21 & & $\mathrm{E}^{+}$ \\
\hline & Mottle & 360 & 164 & 0.09 & 0.11 & $6.2454^{*}$ & mo \\
\hline \multirow[t]{2}{*}{ Feather Structure } & Normal & 2,250 & 1480 & 0.67 & 0.68 & & $\mathrm{~N}^{+}$ \\
\hline & Frizzled & 1083 & 1152 & 0.33 & 0.33 & $5.11577^{*}$ & $\mathrm{Ff}$ \\
\hline
\end{tabular}


taboo to their consumption.

Two variants were observed for the feather morphology, and these were the normal and the silky feather type. The silky type has a fluffy look and in most cases develops into birds having short wings (sw). This situation is as a result of the birds not being able to do away with their down feather while maturing. The birds with normal feather in the population were more dominant.

The plumage colour is controlled by the genes on the $E$ locus. Plumage, which is also referred to as feather, helps to cover the larger part of the body of the birds. It also protects the skin against harsh conditions. Melanocortin 1-receptor (MC1R) mutations are associated with plumage colour in chicken. The variants observed were white, black, brown and mottled with the mottled type being more predominant in the population and the white chicken being the least. The presence of multiple variants of feather colour within the population is also a typical feature characterizing indigenous fowl in other parts of Africa (Gueye, 1998) and Asia (Bhuiyan et al., 2005).

Colour of the ear lobe determines the colour of the egg shell laid. Red ear lobe colour results in a brown colour of the egg shell while birds having white and yellow ear lobes were seen laying eggs having white shells. The eggs with the brown coloured shell are more widely accepted in the South-Western part of Nigeria (Uwagboe $e t$ $a l ., 2009)$ and hence the presence of more chickens with red ear lobe.

The skin and shank colour had two variants; white and yellow with yellow colour being predominant in the two. The skin and shank colour result from type of feed that the bird consume. The yellow skin and shank colour is the result of the expression of the carotenoid pigments in the skin of the birds
(Smyth, 1990). The skin and shank colour is generally considered to be associated with the bird's adaptive fitness that reflects its nutritional status or health that is indicative of its foraging efficiency and immune status (Eriksson et al., 2007).

\section{Conclusion}

This study revealed that significant morphological variability exists among features of indigenous chicken population surveyed in South-Western Nigeria and some of these features have been selected due to their economic importance in the study area.

\section{References}

Adebambo, O.A., Ikeobi, C.O.N., Ozoje, M.O. and Adenowo, J.A. 1999. Colour variations and performance characteristics of the indigenous chicken of South-western Nigeria. Nigerian Journal of Animal Production. 26: 15-22.

Aklilu, H.A. 2007. Village poultry in Ethiopia: Socio-technical analysis and learning with farmers. Wageningen University, Wageningen, The Netherlands. 178 pp. (Ph.D. thesis)

Bhuiyan, A.K.F.H., Bhuiyan, M.S.A. and Deb, G.K. 2005. Indigenous chicken genetic resources in Bangladesh: Current status and future out-look. Animal Genetic Resources Information. 36: 73-84.

Dana, N., Dessie, T., van der Waaij, L.H., and van Arendonk, J.A.M. 2010. Morphological features of indigenous chicken populations of Ethiopia. Animal Genetic Resources. 46: 11-23.

Eriksson, J., Larsen, G., Gunnarsson, U., Bed'hom, B., Tixier-Boichard, M., 
Stromstedt, L., Wright, D., Jungerius, A., Vereijken, A., Randi, E., Jensen, P. and Andersson, L. 2007. Identification of the yellow skin gene reveals the hybrid origin of domestic fowl. PLoS Genetics. 4(2): e1000010

Gueye, E.F. 1998. Village egg and fowl meat production in Africa. World Poult. Sci.J. 54: 73-86.

Gunn, H.H. 2008. Effects of frizzling and naked neck gene on growth, haematology, carcass traits and organ weights of the Nigerian Local chicken. M.Sc. Dissertation, Department of Animal Breeding and Genetics, University of Agriculture, Abeokuta.

Horst, P. 1989. Native fowls as reservoir for genomes and major genes with direct and indirect effect on the adaptability and their potential for tropically oriented breeding plans. Arch. Geflugel. 53(3): 93-101.

Ibe, S.N. 1992. Incorporating adaptability genes in poultry breeding programmes in Nigeria. Proceedings of the XIX World Poultry Congress, Sept. 20-24, Amsterdam, 693-696.

Ibe, S.N. 1993. Growth performance of normal, frizzle and naked neck chicken in a tropical environment. Nigerian Journal of Animal Production. 20: 25-31.

Ikeobi, C.O.N., Ozoje M.O., Adebambo, O.A., Adenowo, J.A. and Osinowo O.A. 1996. Genetic differences in the performance of local chicken in South-western Nigeria. Nigerian Journal of Genetics. 11: 55-60.

Kerje, S., Lind, J., Schütz, K., Jensen, P. and Andersson, L. 2003. Melanocortin 1-receptor (MC1R) mutations are associated with plumage colour in chicken. Animal
Genetics. 34(4): 241-248.

Ng, C.S., Wu, P., Foley, J., Foley, A. and McDonald, M.L. 2012. The chicken frizzle feather is due to an $\alpha$-keratin (KRT75) mutation that causes a defective rachis. PLOS Genetics. 8(7): e1002748.

Oni, O.O. 1999. Potentials for development of poultry foundation stock for Nigeria in the new millennium. Genetics and food security in Nigeria in the twenty first century. Daybis Limited Ibadan. Pp 187-193.

Smyth, J.R. 1990. Genetics of plumage, skin and eye pigmentation in chickens. In R.D. Crawford, ed. Poultry breeding and genetics, Amsterdam, Elsevier Science Publishers. pp. 109-168.

Uwagboe, E.O., Ogunwole, O.A., AbiolaOlagunju, O.I., Akinsoyinu, A.O. and Hamzat, R.A. 2009. Consumer preference for egg shell and yolk colour in Nigeria: A case study of Iddo and Akinyele local government areas of Oyo State. Book of Abstracts, International Poultry Scientific Forum held at the World Congress Center, Atlanta, GA, USA. January 26-27. P179

Weigend, S. and Romanov, M.N. 2001. Current strategies for the assessment and evaluation of genetic diversity in chicken resources. World Poult. Sci.J. 57:275-287.

Wildelitz, R.B., Veltmaat, J.M., Mayer, J.A., Foley, J. and Chuong, C.M. 2007. Mammary glands and feathers: Comparing two skin appendages which help define novel classes during vertebrate evolution. Semin Cell Dev Biol. 18: 255-226

Received: $15^{\text {th }}$ May, 2014 Accepted: $6^{\text {th }}$ November, 2014 